\title{
Physicochemical properties and anti-wrinkle effect of polysaccharides with different molecular weights from Gloiopeltis furcata
}

\author{
Dae-Hoon Lee, Joo-Heon Hong * \\ Department of Food Science and Technology, Catholic University of Daegu, Gyeongsan 38430, Korea
}

\section{불등풀가사리 다당류의 분자량에 따른 이화학적 품질특성 및 피부 주름 개선 효과}

\author{
이대훈 · 홍주헌 * \\ 대구가톨릭대학교 식품공학전공
}

\begin{abstract}
In this study, the physicochemical properties and anti-wrinkle effect of polysaccharides with different molecular weights from Gloiopeltis furcata were investigated. Crude polysaccharides were isolated by viscozyme treatment followed by ethanol precipitation and lyophilization. Crude polysaccharides were hydrolyzed by acid (0.1 N HCl) and the molecular weight fractions were generated by centrifugal filter ( $<10 \mathrm{kDa}, 10$ to $100 \mathrm{kDa}$, and $100 \mathrm{kDa}>$ ). The yield of polysaccharides with different molecular weight fractions was 8.4-39.6\%. The major constituents in molecular weight fractions were total sugar (81.37-85.82\%), uronic acid (27.89-32.85 g/100 g), sulfate (33.38-39.04\%), and protein (0.35-3.16\%) The $\mathrm{L}$, $a$, and $\mathrm{b}$ value of the $100 \mathrm{kDa}$ group were decreased, but viscosity increased. The oxygen radical absorbance capacity of the $100 \mathrm{kDa}$ group at $180.07 \mu \mathrm{M}$ was the highest among groups. The protective effects of $100 \mathrm{kDa}$ group at 0.5 and $5 \mu \mathrm{g} / \mathrm{mL}$ against $\mathrm{H}_{2} \mathrm{O}_{2}$-induced cytotoxicity in $\mathrm{L132}$ cell were 87.34\% and $103.85 \%$, respectively. The matrix metalloproteinase-1 activity of $100 \mathrm{kDa}$ group decreased in a dose-dependent manner. The pro-collagen synthesis activity of $100 \mathrm{kDa}$ group at $0.05-0.5 \mu \mathrm{g} / \mathrm{mL}$ was $64.91-77.80 \%$. The polysaccharides with different molecular weights from Gloiopeltis furcata investigated herein are useful as a potential candidate for cosmedical materials.
\end{abstract}

Key words : Gloiopeltis furcata, polysaccharides, different molecular weights, physicochemical properties, anti-wrinkle effect

\section{서 론}

최근 현대인들의 경제 수준 향상과 의학의 발전으로 평 균수명 및 삶의 질이 향상됨에 따라 피부 건강에 대한 관심 이 증대되고 있다(1). 피부 노화 현상은 광노화로 인해 진피 의 collagen을 포함한 결합 조직 성분을 분해하는 matrix metalloproteinases(MMPs)의 활성이 증가하여 피부 조직 내

*Corresponding author. E-mail : jhhong@cu.ac.kr

Phone : 82-53-850-3218, Fax : 82-53-850-3218

Received 17 August 2017; Revised 23 August 2017; Accepted 23 August 2017.

Copyright (c) The Korean Society of Food Preservation. All rights reserved.
의 collagen 함량이 저하되기 때문이며, 자외선 조사량이 증가할수록 MMPs의 활성이 증가하는 것으로 보고되고 있 다(2). 피부에서의 콜라겐 함량은 고령화에 따른 내인성 노화 및 자외선 노출에 의한 광노화에 의해 영향을 받으며, 피부 노화가 진행됨에 따라 피부 내의 MMP-1 활성은 증가 하는데 이는 피부의 콜라겐 함량 감소에 따른 탄력 저하와 주름 생성을 유발한다(3). 또한, 피부 진피에 구조적인 지지 를 제공하는 세포외 기질의 일차적인 구성요소인 collagen type I 과 pro-collagen은 자외선에 의해 하향조절되어 피부 노화를 촉진하게 된다(4). 이러한 피부 주름 개선 효능에 대한 연구가 다양하게 진행되고 있으나 기존의 미백 및 주름 개선 소재인 vitamin $\mathrm{C}$, arbutin, retinol 및 a-hydroxyl acid 등은 빛과 열에 불안정하고 피부 자극이 유발되는 것으 
로 알려져 있다(5,6). 따라서 많은 연구자는 천연물에서 피 부 미용소재를 개발하고자 노력하고 있으며, 주름 예방 및 개선을 위해서는 콜라겐 합성 증진 및 콜라겐 분해 효소 억제력이 중요한 것으로 알려져 있다(7).

홍조류에 속하는 불등풀가사리(Gloiopeltis furcata)는 한 국, 일본 및 미국 태평양 연안 등에 분포하고 있다. 불등풀가 사리의 형태는 적갈색을 나타내고 외부는 가죽질의 긴 막대 모양으로 속은 비어 있고 점 액질이 풍부하며 풀가사리와 외형상 유사하나 줄기의 속이 비어 있는 차이점이 있다(8). 불등풀가사리에 주로 함유된 다당류는 자연에 널리 분포하 고 있으며 해양생물, 식물 및 해조류에 의해 생성 및 파생되 고 해조 다당류의 성질을 결정하는 주요 구성성분인 황산기 가 많이 함유되어 있다고 보고되어 있다(9). 이러한 다당류 는 sulfate 함량과 분자량, 당골격의 sulfate 위치, 당성분에 의존적으로 항산화 및 세포 재생 효과 등의 기능성을 나타 내고 있다(10). 일반적으로 다당류를 가수분해하여 저분자 화하면 기능성이 증진되는 것으로 알려져 있고, 카라기난 및 알긴산 등과 같은 고분자 다당류를 적절히 가수분해하면 다당류의 분자량 크기에 따라 항산화, 항염증 및 면역작용 등의 다양한 기능성을 나타낸다고 알려져 있다 $(11,12)$.

따라서 본 연구에서는 불등풀가사리 유래 유용물질인 다당류를 추출한 다음 저분자화를 위해 산가수분해하였으 며, 분자량별로 분리한 후 식품 및 화장품 산업에서 기능성 소재로의 활용 가능성을 확인하기 위해 이화학적 품질특성 및 피부 주름 개선 효과에 대하여 조사하였다.

\section{재료 및 방법}

\section{실험재료}

본 실험에 사용한 불등풀가사리는 전라남도 완도군에서 채취한 것을 (유)제일물산에서 구입하여 본 실험에 사용하 였으며, 흐르는 물에 씻고 열풍 건조기(OF-22, JEIO TEC, Daejeon, Korea)로 $50^{\circ} \mathrm{C}$ 에서 24시간 건조하였다. 건조된 불 등풀가사리는 분쇄기(FM-909W, Hanil, Co., Sejong, Korea) 로 분쇄한 후 $60 \mathrm{mesh}$ 이하의 분말을 $-20^{\circ} \mathrm{C}$ 냉동고에 보관하 면서 조다당류 추출용 시료로 사용하였다.

\section{조다당류 제조}

조다당류를 분리하기 위해 건조 분말 $5 \mathrm{~g}$ 에 증류수를 고형분 대비 50배 첨가한 다음 viscozyme(Viscozyme L, 100 FBG $/ g$, Novozymes A/S, Bagsvaerd, Denmark)을 기질 대비 $3 \%$ 첨가하여 shaking water bath(BS-31, Jeio Tech., Daejeon, Korea)에서 $150 \mathrm{rpm}, 60^{\circ} \mathrm{C}, 14$ 시간 교반하였다. 교반한 시료 는 원심분리 $(3,000 \times g, 30$ 분 $)$ 한 다음 회수하여 상등액을 감압 농축기(Model N-1N, Eyela Co., Tokyo, Japan)로 60 ${ }^{\circ} \mathrm{Brix}$ 가 될 때까지 농축하였다. 농축액은 5 배량의 에탄올을
첨가하여 24 시간 교반하고 원심분리 $(3,000 \times g, 30$ 분 $)$ 하여 조다당류를 회수하였고 동결건조(Freezone 2.5, Labconco Co., USA)한 다음 $-70^{\circ} \mathrm{C}$ 이하에서 보관하면서 산가수분해 및 분자량별 분리 시료로 사용하였다.

\section{다당류의 분자량별 분리}

불등풀가사리 유래 조다당류를 $0.1 \mathrm{~N} \mathrm{HCl}$ 을 사용하여 $1 \%$ 용액으로 조정한 다음 $50^{\circ} \mathrm{C}$ 에서 4 시간 동안 shaking water bath(BS-31, Jeio Tech.)에서 교반하였다. 교반을 통해 가수분해된 다당류는 $0.1 \mathrm{~N} \mathrm{NaOH}$ 를 사용하여 $\mathrm{pH}$ 를 중성화 한 다음 다당류를 24시간 동안 투석하여 산가수분해된 다 당류를 제조하였다. 산가수분해 다당류를 분자량별로 분리 하기 위해 amicon Ultra-15 centrifugal filter(Merck Millipore, Tullagreen Carrigtwohill, Ireland)를 이용하여 $10 \mathrm{kDa}$ 이하, $10-100 \mathrm{kDa}$ 및 $100 \mathrm{kDa}$ 이상으로 분리한 다음 동결건조 하여 실험에 사용하였다.

\section{수 율}

불등풀가사리로부터 추출한 조다당류와 조다당류를 산 가수분해한 다음 분자량별로 분리한 다당류의 수율은 동결 건조(FreeZone 2.5, Labconco Co., Kansas, MO, USA)한 다 음 건물 중량을 구한 다음 시료 제조에 사용한 원료 건물량 에 대한 백분율로 나타내었다.

\section{총 당 및 총 단백질 함량}

총 당 함량 분석은 $\mathrm{Saha}$ 와 Brewer(13)의 방법에 따라 페 놀-황산법으로 분석하였다. 즉 $5 \%$ phenol $1 \mathrm{~mL}(\mathrm{w} / \mathrm{v}$, Duksan Pure Chemicals, Seoul, Korea)와 sulfuric acid(Duksan Pure Chemicals) $5 \mathrm{~mL}$ 를 $0.2 \mathrm{mg} / \mathrm{mL}$ 농도로 희석한 시료 $1 \mathrm{~mL}$ 와 반응시킨 후 분광광도계(Ultraspec 2100pro, Amersham Co., Uppsala, Sweden)를 사용하여 $525 \mathrm{~nm}$ 에서 흡광도를 측정하 고 glucose(Sigma-Aldrich Co., St. Louis, MO, USA)를 표준 곡선으로 이용하여 계산하였다.

총 단백질 함량은 Lowry 등(14)의 방법으로 측정하였으 며 bovine serum albumin(BSA, Sigma-Aldrich Co.)을 표준 곡선으로 이용하여 계산하였다.

\section{Uronic acid 함량 및 sulfate 함량}

Uronic acid 함량은 Cesaretti 등(15)의 방법에 따라 분석 하였다. 즉, $25 \mathrm{mM}$ sodium tetraborate(Sigma-Aldrich Co.)를 진한 황산 용액으로 제조한 후 이 용액 $0.2 \mathrm{~mL}$ 와 $0.2 \mathrm{mg} / \mathrm{mL}$ 농도로 희석한 시료 $0.05 \mathrm{~mL}$ 를 96-well plate에 넣고 잘 섞은 후 $100^{\circ} \mathrm{C}$ 에서 10 분간 가열하였다. 그 다음 상온에서 15 분 방냉한 후 $0.125 \%$ carbazole(Sigma-Aldrich Co.) 0.05 $\mathrm{mL}$ 를 가하고 $100^{\circ} \mathrm{C}$ 에서 10 분간 가열한 다음 상온에서 15 분 방냉하고 $550 \mathrm{~nm}$ microplate reader(Asys UVM340, Biochrom, Eugendorf, Austria)로 흡광도를 측정한 후, galacturonic 
acid(Sigma-Aldrich Co.)로 작성한 표준곡선으로부터 함량 을 계산하였다.

Sulfate 함량은 Dodgson 과 Price(16)의 방법으로 분석하 였다. 시료 $3 \mathrm{mg}$ 에 $6 \mathrm{~N}$ hydrochloric $\operatorname{acid}(\mathrm{HCl}$, Duksan Pure Chemicals.) $10 \mathrm{~mL}$ 를 가한 후 $110^{\circ} \mathrm{C}$ 에서 6시간 가수분해하 였다. 가수분해한 시료 $0.2 \mathrm{~mL}$ 에 $3 \%$ trichloroacetic acid (TCA, Acros organics, Geel, Belgium)를 $3.8 \mathrm{~mL}$ 및 $\mathrm{BaCl}_{2}$-gelatin 용액 $1 \mathrm{~mL}$ 를 가하고 $25^{\circ} \mathrm{C}$ 에서 15 분간 반응한 다음 $360 \mathrm{~nm}$ 에서 분광광도계(Ultraspec 2100pro, Amersham Co.)를 사용하여 흡광도를 측정하였으며, potassium sulfate(Sigma-Aldrich Co.)를 이용하여 작성한 표준곡선으 로부터 계산하였다.

\section{색도 측정}

색도 측정은 분말을 표준색도은 $\mathrm{Y}=94.5, \mathrm{a}=0.18, \mathrm{~b}=0.32$ 로 보정된 색차계(Chromameter CR400, Minolta Co, Osaka, Japan)를 사용하여, 밝기를 나타내는 L(lightness), 적색도를 나타내는 a(redness), 황색도을 나타내는 b(yellowness)값을 측정하였으며, 색차 $\Delta \mathrm{E}$ 는 조다당류 동결건조 분말을 대조 구로 하여 아래와 같이 계산하였다.

$$
\Delta \mathrm{E}=\sqrt{\Delta L^{2}+\Delta a^{2}+\Delta b^{2}}
$$

\section{점 도}

점도는 회전식 점도계인 first LR touch viscometer(Lamy Rheology Instruments, Champagne au Mont d'Or, France)를 사용하여, $0.5 \%$ 농도의 시료 용액을 spindle L-2로 $25^{\circ} \mathrm{C}$, $60 \mathrm{rpm}$ 에서 측정하였다.

\section{ORAC 측정}

ORAC(oxygen radical absorbance capacity) 측정은 Talcott 와 Lee(17)가 항산화 활성 측정에 사용한 분석법을 이용하 였다. 분석용 시료 및 water soluble analogue of vitamin $\mathrm{E}$, 6-hydroxy-2,5,7,8-tetramethylchroman-2-carboxylic acid(Trolox, Sigma-Aldrich Co.)를 농도별로 희석하였으며, 분석용 시료의 제조에는 중성 phosphate buffer(61.6:38.9, $\mathrm{v} / \mathrm{v}, 0.75 \mathrm{M} \mathrm{K}_{2} \mathrm{HPO}_{4}$ 와 $\left.0.75 \mathrm{M} \mathrm{NaH}_{2} \mathrm{PO}_{4}\right)$ 를 사용하였다. 검량 곡선을 작성하기 위하여 항산화 활성 비교 표준액으로 trolox를 $10 \mu \mathrm{L}$ 를 phosphate buffer $50 \mathrm{~mL}$ 에 용해하여 제조하 였고, 측정기기는 fluorescent micro plate reader(Infinite M200 PRO, Tecan Co., Salzburg, Austria)를 사용하여 485 $\mathrm{nm}$ 에서 전자가 여기(excitation)되고 $538 \mathrm{~nm}$ 에서 방출 (emission)되게 조절하여 본 실험에 적용되었다.

\section{세포주 및 세포 배양 방법}

실험에 이용한 폐 정상세포(L132)는 한국 세포주 은행 (KTCC, Seoul, Korea)에서 구입하여 RPMI 1640(Welgene,
Daegu, Korea) 배지를 사용하였고, 사람 진피 섬유아세포주 (HS68)는 American Type Culture Collection(ATCC)에서 분 양받아 Dulbecco's modified Eagle's medium(DMEM, Welgene.) 배지에 $10 \% \mathrm{FBS}$ 및 $100 \mathrm{unit} / \mathrm{mL}$ penicillin, 100 $\mathrm{ng} / \mathrm{mL}$ streptomycin을 첨가하여 $37^{\circ} \mathrm{C}, 5 \% \mathrm{CO}_{2}$ incubator (MCO-18AIC, SANYO Co., Sakata, Japan)에 적응시켜 각각 배양시켰다.

\section{세포 독성}

L132 및 HS68 세포에 대한 독성은 MTT assay로 측정하 였으며, 배양된 세포주를 $5 \times 10^{4} \mathrm{cell} / \mathrm{well}$ 의 농도로 조정하 여 96 well plate에 $100 \mu \mathrm{L}$ 씩 첨가하여 24시간 배양하고, 이후 새로운 배지에 시료를 농도별로 처리한 다음 24시간 동안 배양하였다. 배양 후 PBS 완충용액에 녹인 methyl thiazol-2-YL-2, 5-diphenyl tetrazolium bromide(MTT 5 $\mathrm{mg} / \mathrm{mL}$, Sigma-Aldrich Co.)용액을 각 well에 $10 \mu \mathrm{L}$ 씩 첨가 하고 다시 4시간 동안 배양하여 MTT가 환원되도록 하였다. 이후 상등액을 완전히 제거하고 dimethyl sulfoxide(DMSO, Junsei Chemical Co., Tokyo, Japan) $100 \mu \mathrm{L}$ 를 각 well에 첨가 하여 10 분간 반응시켜 formazan 결정을 완전히 용해한 다음 microplate reader(UVM-340, ASYS Co.)를 이용하여 $540 \mathrm{~nm}$ 에서 흡광도를 측정하였다.

\section{산화적 손상에 대한 세포보호 효과}

$\mathrm{L} 132$ 세포에 $\mathrm{H}_{2} \mathrm{O}_{2}$ 에 의해 유도된 산화적 손상에 대한 세포보호 효과를 측정하기 위해 MTT assay를 실시하였으 며, L132 세포를 96 well plate에 $5 \times 10^{4}$ cells/well로 분주하고 incubator에서 24시간 동안 배양하였다. 배양 후 시료를 처 리하고 24시간 동안 배양한 다음 $\mathrm{H}_{2} \mathrm{O}_{2}$ (Duksan Pure Chemicals.)를 $1 \mathrm{mM}$ 의 농도로 첨가하고 30 분간 반응 후 L132 세포에 MTT $(5 \mathrm{mg} / \mathrm{mL}$, Sigma-Aldrich Co.)를 처리하 여 $37^{\circ} \mathrm{C}$ 에서 4 시간 반응시켰다. 그 후 상등액을 제거하고 각 well에 $200 \mu \mathrm{L}$ 의 dimethyl sulfoxide(DMSO)를 첨가한 다음 microplate reader(UVM-340, ASYS Co.)를 사용하여 $540 \mathrm{~nm}$ 에서 흡광도를 측정하였고 세포보호 효과는 시료의 흡광도를 대조군의 흡광도에 대한 백분율로 나타내었다.

\section{$\mathrm{MMP}-1$ 활성 측정}

Ultraviolet B(UVB)로 손상된 피부 세포로부터 다당류의 분자량에 따른 영향을 조사하기 위해, HS68 세포주에 UVB 를 조사한 후 광노화를 유도한 다음 24 well plate에서 $5 \times 10^{4}$ cells/well 농도로 분주하고 24시간 배양하여 세포를 부착하 였다. 이후, UVB 조사는 UV 램프를 이용하여 UVB (280-320 nm)를 $20 \mathrm{~mJ} / \mathrm{cm}^{2}$ 되게 조사하였다. 이 때, UVB 조사량은 Chiang 등(18)의 보고에 따라 세포 생존율에 영향 을 주지 않으면서 matrix metalloproteinase(MMPs) 유도가 일어나도록 설정하였으며 UV-radiometer(LP9021, Delta 
$\mathrm{OHM}$, Padua, Veneto, Italy)를 이용하여 조사량을 측정하였 다. 시료에 의한 MMP-1 활성 변화는 상기와 같이 UVB를 조사한 세포에 배지와 함께 시료를 처리하고 24시간 추가 배양한 다음 원심분리 $(3,000 \times g, 10$ 분 $)$ 후 상등액을 회수하 여 matrix metalloproteinase-1(MMP-1) human biotrak에 대 해 ELISA system(Amersham life science, Arlington Heights, $\mathrm{IL}, \mathrm{USA}$ )을 이용하여 MMP-1 발현을 측정하였다.

\section{Pro-collagen 생합성 측정}

HS68 세포주에 분자량별로 분리된 다당류를 농도별로 처리한 다음 pro-collagen type I의 합성양을 측정하기 위해 24 well plate에 각 well당 $5 \times 10^{4}$ cells/well 농도로 분주하고 24 시간 배양하여 세포를 부착하였다. 이후, UVB 조사는 MMP-1 저해활성과 동일하게 진행하였으며, 배양된 배지 를 제거하고 분자량별로 분리된 다당류를 농도별로 처리한 후 24시간 배양하였다. 각 well 로부터 상등액을 회수하여 procollagen type-I c-peptide EIA kit(Takara-Bio Inc., Shiga, Japan)의 각 well에 첨가한 후 제조사의 방법에 따라 procollagen type $\mathrm{I}$ 의 총 양을 측정 하였다.

\section{통계 처리}

실험결과는 3회 반복실험의 평균표준편차로 나타내었 고 SPSS(19.0, SPSS Inc., Chicago, IL, USA)를 이용하여 분산분석(ANOVA)을 실시하였고 각 측정 평균값의 유의 성 $(\mathrm{P}<0.05)$ 은 Duncan's multiple range test로 검정하였다.

\section{결과 및 고찰}

\section{다당류의 이화학적 특성}

조다당류 및 산가수분해된 분자량별 다당류의 수율, 총 당, uronic acid, sulfate 및 총단백질 함량은 Table 1에 나타내 었다. 산가수분해된 분자량별 다당류의 수율은 100 $\mathrm{kDa}(\mathrm{GPA}-\mathrm{III})$ 이상에서 $39.6 \%$ 로 가장 높았으며, $10-100$ $\mathrm{kDa}(\mathrm{GPA}-\Pi) 8.4 \%$ 및 $10 \mathrm{kDa}(\mathrm{GPA}-\mathrm{I})$ 이하에서 $10.4 \%$ 를
나타내어 가장 낮은 수율을 나타내었다. 이는 Kim 등(19)의 Porphyra tenera(해조류, 김) 가수분해물의 분자량별 분획 수율에서 분자량이 감소할수록 수율이 감소한다고 보고하 여 본 연구결과와 유사한 경향을 나타내었다. 총당, uronic acid 및 sulfate 함량은 $100 \mathrm{kDa}$ 이상에서 각각 $85.82 \%, 32.85$ $\mathrm{g} / 100 \mathrm{~g}$ 및 $39.04 \%$ 의 함량을 나타내어 가장 높았고, $10 \mathrm{kDa}$ 이하 분자량에서 $81.37 \%, 27.89 \mathrm{~g} / 100 \mathrm{~g}$ 및 $33.38 \%$ 를 나타내 어 가장 낮은 함량을 나타내었다. 총단백질 함량은 $0.35-3.16 \%$ 의 함량이었고 분자량이 낮을수록 높은 단백질 함량을 나타내었다. 이는 Hou 등(20)의 laminaria japonica (다시마) 후코이단의 분자량별 $(1-144.5 \mathrm{kDa})$ 연구에서 총당 및 sulfate 함량은 분자량에 따라 다르게 나타난다고 보고하 였으며, 다당류의 산가수분해 처리로 인해 증가한 총당, uronic acid 및 sulfate와 다양한 구성 성분에 의해 항산화 활성, 면역 및 항보체 활성 및 피부 미백 및 주름 개선에 영향을 미친다고 알려져 있다 $(21,22)$. 불등풀가사리 유래 조다당류의 산가수분해에 따른 유용물질 함량 증가와 분자 량의 차이는 다양한 생리활성에 영향을 줄 것으로 사료된 다.

\section{색도 및 점도}

조다당류 및 분자량별 다당류 $(10 \mathrm{kDa}, 10-100 \mathrm{kDa}$ 및 $100 \mathrm{kDa}$ )의 색도은 조다당류 $\mathrm{L}$ 값, $\mathrm{a}$ 값 및 $\mathrm{b}$ 값이 각각 $69.28,-1.17$ 및 10.39를 나타내었으며, 산가수분해 다당에 서는 분자량이 감소함에 따라 $\mathrm{L}$ 값(81.75-85.96), $\mathrm{a}$ 값 (-0.63-1.50) 및 b 값(10.03-12.61)은 증가하는 경향을 나타내 었다. 특히 조다당류를 기준으로 본 $\Delta \mathrm{E}$ 값은 $\mathrm{GPA}-\mathrm{II}$ 에서 12.49 로 가장 낮고 GPA-I 에서 17.04로 가장 높게 나타나 산가수분해 다당에서는 분자량이 감소할수록 색도의 변화 가 증가하였다. 이는 Fukumoto 등(23)의 사과 주스의 분자 량별 색도 변화 연구에서 저분자 물질과 당, 색소물질 및 혼탁물질에 의해 색도이 변화된다고 보고하였으며 불등풀 가사리사리 유래 조다당류의 산가수분해를 통해 분자량별 색상이 다른것으로 나타났다.

Table 1. Yields, sugar, uronic acid, sulfate and protein contents of crude polysaccharide and polysaccharides with different molecular weights from Gloiopeltis furcata

\begin{tabular}{cccccc}
\hline Samples ${ }^{1)}$ & $\begin{array}{c}\text { Yield } \\
(\%)\end{array}$ & $\begin{array}{c}\text { Sugar content } \\
(\text { glucose }, \%)\end{array}$ & $\begin{array}{c}\text { Uronic acid content } \\
\left(\mathrm{GA}^{2)}, \mathrm{g} / 100 \mathrm{~g}\right)\end{array}$ & $\begin{array}{c}\text { Sulfate content } \\
\left(\mathrm{PS}^{3)}, \%\right)\end{array}$ & $\begin{array}{c}\text { Protein content } \\
\left(\mathrm{BSA}^{4)}, \%\right)\end{array}$ \\
\hline GCP & 60.1 & $\left.70.93 \pm 1.42^{\mathrm{c}}\right)$ & $18.68 \pm 0.74^{\mathrm{d}}$ & $32.79 \pm 0.46^{\mathrm{c}}$ & $3.98 \pm 0.27^{\mathrm{a}}$ \\
GPA- I & 10.4 & $81.37 \pm 1.67^{\mathrm{b}}$ & $27.89 \pm 0.57^{\mathrm{c}}$ & $33.38 \pm 0.32^{\mathrm{c}}$ & $3.16 \pm 0.45^{\mathrm{b}}$ \\
GPA- II & 8.4 & $83.76 \pm 0.12^{\mathrm{a}}$ & $30.66 \pm 0.50^{\mathrm{b}}$ & $35.87 \pm 0.29^{\mathrm{b}}$ & $0.88 \pm 0.24^{\mathrm{c}}$ \\
GPA-III & 39.6 & $85.82 \pm 0.60^{\mathrm{a}}$ & $32.85 \pm 0.93^{\mathrm{a}}$ & $39.04 \pm 0.31^{\mathrm{a}}$ & $0.35 \pm 0.12^{\mathrm{c}}$ \\
\hline
\end{tabular}

${ }^{1)} \mathrm{GCP}$, crude polysaccharide; GPA- I, polysaccharides with molecular weight $<10 \mathrm{kDa}$; GPA-II, polysaccharides with molecular weight 10-100 kDa; GPA-III, polysaccharides with molecular weight $>100 \mathrm{kDa}$.

${ }^{2)} \mathrm{GA}$, galacturonic acid.

${ }^{3)} \mathrm{PS}$, potassium sulfate.

${ }^{4)} \mathrm{BSA}$, bovine serum albumin.

${ }^{5)}$ The values are means \pm SD of three experimental data. Means with different superscripts in the same column are significantly different at $p<0.05$. 
분자량별 다당류의 따른 점도는 분해 전 조다당류의 경 우 $40.36 \mathrm{cP}$ 에서 $10 \mathrm{kDa}$ 이하인 GPA- I은 $18.33 \mathrm{cP}$ 로 점도 가 감소하였으며, GPA-피 $33.41 \mathrm{cP}$ 로 점도가 가장 높게 나타났다. 이는 Lee 등(24)의 알긴산의 물성에 미치는 저분 자화 영향 연구에서 저분자화를 통해 점성은 저하되고, 유 화능 및 흡유능은 증가한다고 보고하였으며, 이는 분자량 과 밀접한 상관성 및 $-\mathrm{COOH}$ 기 등의 기능기들의 노출 증가 에 의한 것으로 알려져 조다당류의 산가수분해를 통해 산업 적 활용도가 증대될 것으로 판단된다.

\section{ORAC 활성}

Oxygen radical absorbance capacity(ORAC) assay는 측정 방법이 간단하고 재현성이 뛰어나 폭넓게 활용되고 있는 방법으로, 2,2'-Azobis(2-methylpropionamidine) dihydrochloride (AAPH)로부터 유도된 peroxyl radical에 대한 소거활성을 형 광도로 측정하며, peroxyl radical 손상에 대한 억제 시간과 억제율을 모두 반영하는 측정 방법이다(25).

불등풀가사리 유래 산가수분해된 분자량별 다당류의 ORAC 분석 결과는 Fig. 1 과 같다. $500 \mu \mathrm{g} / \mathrm{mL}$ 의 농도에서 측정한 $\mathrm{ORAC}$ 값은 $\mathrm{GPA}-\mathrm{II}$ 에서 $180.07 \mu \mathrm{M}$ 로 가장 높은 항산화 활성을 나타내었으며, GPA- I 및 GPA- П에서 각각 $135.11 \mu \mathrm{M}, 152.49 \mu \mathrm{M}$ 로 활성을 나타내어 조다당류 34.70 $\mu \mathrm{M}$ 에 비해 높은 항산화 활성을 나타내었다. 이는 Lee와 Hong(20)의 추출조건에 따른 오만둥이 유래 다당류의 항산 화활성 연구에서 $\mathrm{ORAC}$ 값은 $295.07 \mu \mathrm{M}$ 의 활성을 나타내어 본 연구와 유사한 경향을 나타내었다. 또한, Hou 등(20)은 laminaria japonica 후코이단의 분자량별 항산화 활성 연구 에서 항산화 활성은 분자량에 따라 차이를 나타내었으며 $80 \mathrm{kDa}$ 에서 가장 높은 활성을 나타낸다고 보고하였다. 이러

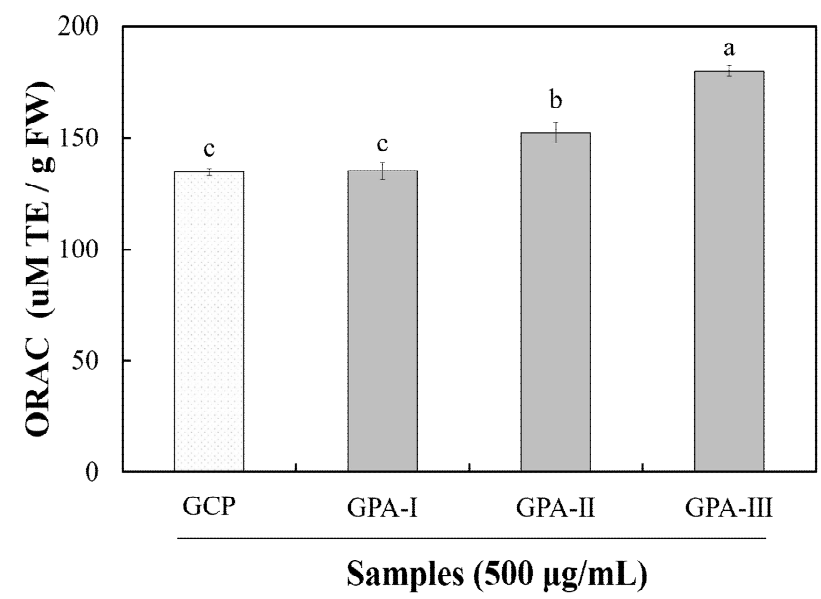

Fig. 1. Oxygen radical absorbance capacity (ORAC) of crude polysaccharide from Gloiopeltis furcata and its fractions with different molecular weight.

GCP, crude polysaccharide; GPA- I, polysaccharides with molecular weight $<10 \mathrm{kDa}$; GPA- II, polysaccharides with molecular weight $10-100 \mathrm{kDa}$; GPA-III, polysaccharides with molecular weight $>100 \mathrm{kDa}$.
한 항산화 활성의 차이는 다당류의 공간구조 차이와 황산기 함량에 의한 것이라고 보고되고 있으며(27), 자외선에 의한 활성 산소종의 생성과 MMPs의 발현은 노화를 촉진하므로 불등풀가사리 유래 산가수분해된 다당류에 의해 피부 노화 개선과 MMP-1 합성을 효과적으로 저해할 수 있을 것으로 사료된다.

\section{산화적 손상에 대한 보호효과}

조다당류와 산가수분해된 분자량별 다당류를 폐 정상세 포(L132)에 농도별로 처리한 다음 MTT 방법으로 세포 독 성을 측정하였다(Fig $2 \mathrm{~A}$ ). 산가수분해 다당류 분자량별 시 료를 0.5-5 $\mu \mathrm{g} / \mathrm{mL}$ 농도까지 유의적인 세포 사멸이 나타나지 않아 독성이 없음을 확인하여 세포 보호효과 실험 농도로 설정하였다. 불등풀가사리 유래 조다당류 및 분자량별 다
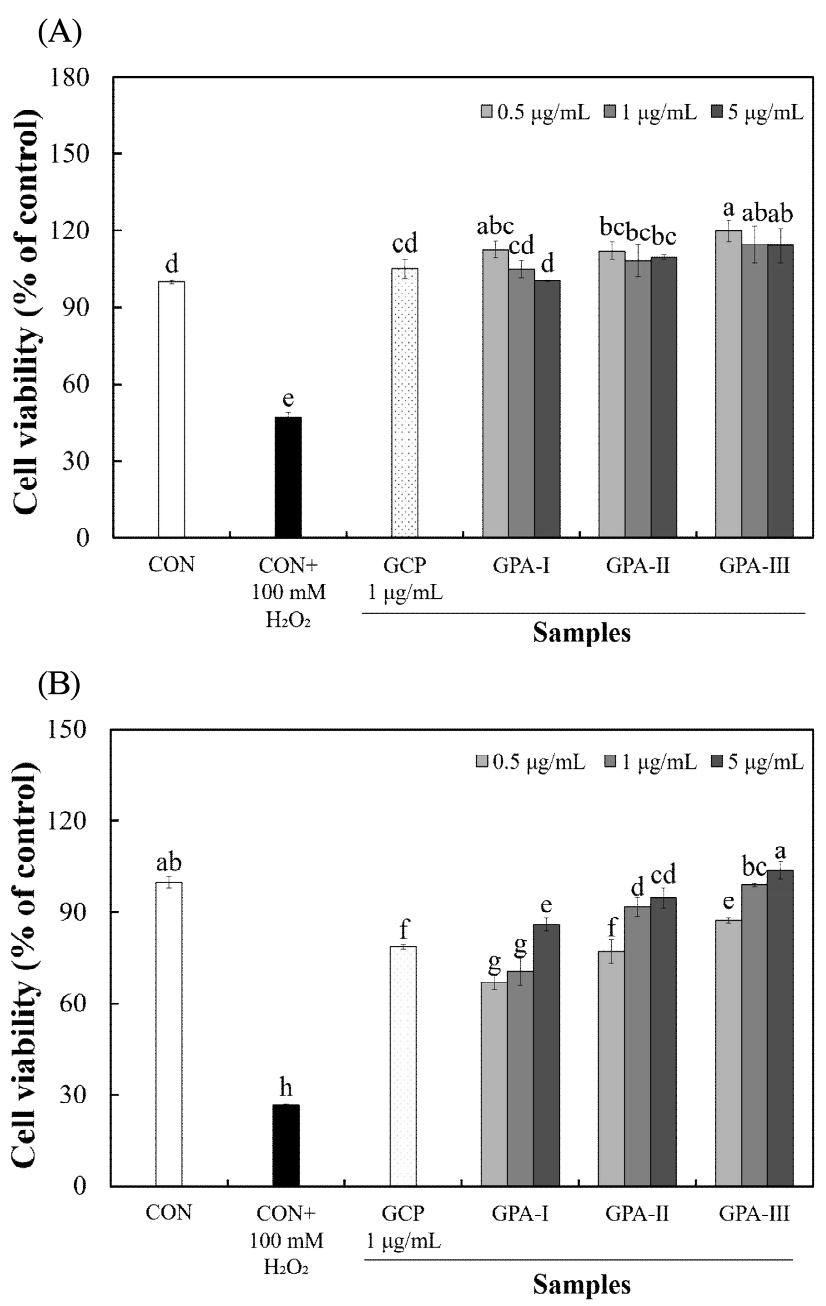

Fig. 2. Effect of crude polysaccharide and polysaccharides with different molecular weights from Gloiopeltis furcata on the cell viability of L-132 cell.

(A), Cytotoxicity; (B), Protective effect against $\mathrm{H} 2 \mathrm{O} 2$ induced cytotoxicity. GCP, crude polysaccharide; GPA- I, polysaccharides with molecular weight $<10 \mathrm{kDa}$; GPA-II, polysaccharides with molecular weight 10-100 kDa; GPA-III, polysaccharides with molecular weight $>100 \mathrm{kDa}$. 
Table 2. Hunter color value and viscosity of crude polysaccharide and polysaccharides with different molecular weights from Gloiopeltis furcata

\begin{tabular}{cccccc}
\hline \multirow{2}{*}{ Samples $^{1)}$} & \multicolumn{3}{c}{ Hunter color value } & $\Delta \mathrm{E}$ & \begin{tabular}{c} 
Viscosity \\
\cline { 2 - 4 }$(\mathrm{cP})$
\end{tabular} \\
\cline { 2 - 5 } GCP & $69.28 \pm 1.13^{\mathrm{c} 2)}$ & $-1.17 \pm 0.08^{\mathrm{c}}$ & $10.39 \pm 0.32^{\mathrm{c}}$ & - & $40.36 \pm 0.12^{\mathrm{a}}$ \\
GPA- I & $85.96 \pm 0.22^{\mathrm{a}}$ & $1.50 \pm 0.02^{\mathrm{a}}$ & $12.61 \pm 0.15^{\mathrm{a}}$ & $17.04 \pm 0.19^{\mathrm{a}}$ & $18.33 \pm 0.41^{\mathrm{d}}$ \\
GPA- II & $84.95 \pm 0.08^{\mathrm{a}}$ & $1.38 \pm 0.02^{\mathrm{a}}$ & $10.99 \pm 0.09^{\mathrm{b}}$ & $15.89 \pm 0.08^{\mathrm{b}}$ & $30.97 \pm 0.26^{\mathrm{c}}$ \\
GPA-III & $81.75 \pm 0.44^{\mathrm{b}}$ & $-0.63 \pm .05^{\mathrm{b}}$ & $10.03 \pm 0.37^{\mathrm{c}}$ & $12.49 \pm 0.44^{\mathrm{c}}$ & $33.41 \pm 0.18^{\mathrm{b}}$ \\
\hline
\end{tabular}

${ }^{11} \mathrm{GCP}$, crude polysaccharide; GPA- I , polysaccharides with molecular weight $<10$ $\mathrm{kDa}$; GPA- $\Pi$, polysaccharides with molecular weight 10-100 kDa; GPA-III, polysaccharides with molecular weight $>100 \mathrm{kDa}$.

${ }^{2}$ The values are means $\pm S D$ of three experimental data. Means with different superscripts in the same column are significantly different at $p<0.05$.

당류의 산화적 손상에 대한 세포 보호효과를 알아보기 위하 여, $\mathrm{H}_{2} \mathrm{O}_{2}$ 처리 후 $\mathrm{L} 132$ 세포에 대한 산화적 손상을 유발 한 다음 세포 생존율을 측정하였다(Fig 2B). 세포 보호효과 분석에 사용되는 $\mathrm{H}_{2} \mathrm{O}_{2}$ 는 쉽게 원형질막을 통과하기 때문에 in vitro 또는 in vivo 실험의 다양한 생리학적 및 병리학적 조건에서 산화적 손상을 유발하는 독성 물질로 이용되고 있다(28). 산화적 손상 유발 후 분자량별 다당류의 세포 보호효과는 GPA-III 0.5-5 $\mathrm{\mu g} / \mathrm{mL}$ 농도에서 87.34-103.85\% 로 가장 높은 세포 보호효과를 나타내었으며, GPA- I 및 GPA- $\Pi$ 에서 각각 66.96-86.04\% 및 77.03-94.76\%의 활성을 보여주어 $1 \mu \mathrm{g} / \mathrm{mL}$ 농도에서 조다당류(83.64\%)에 비해 높은 세포 보호효과를 나타내었다. Lee(29)는 불등풀가사리에 의한 gDNA 산화 억제활성 연구에서 $\mathrm{H}_{2} \mathrm{O}_{2}$ 에 의해 산화된 $\mathrm{DNA}$ 는 불등풀가사리에 의해 산화적 손상 감소 효과를 나 타낸다고 보고하였으며, 이는 ROS 소거활성과 관련된 것 으로 보고하였다. 따라서 불등풀가사리 유래 산가수분해된 다당류는 산화적 손상을 감소시킴으로써 세포 보호효과를 증가시키는 것으로 사료된다.

\section{$M M P-I$ 활성}

불등풀가사리 유래 분자량별 다당류를 HS68 세포주에 0.05-1 $\mathrm{\mu g} / \mathrm{mL}$ 농도로 처리한 결과 독성이 없음을 확인하였 으며(Fig. 3A), UVB 처리를 이용한 MMP-1 활성을 측정하 였다. MMP-1은 type I collagenase로도 불리며 세포외 기 질 및 type I pro-collagen을 분해함으로써 collagen 합성을 저해하는 인자로 알려져 MMP-1 활성 저해는 곧 collagen 분해를 감소시켜 피부 탄력 유지 및 주름 형성을 억제 할 수 있다(30). HS68 세포주에 UVB를 조사하고 분자량별 다당류의 MMP-1 활성 측정 결과는 Fig. $3 \mathrm{~B}$ 에 나타내었다. $\mathrm{HS} 68$ 세포주에 UVB를 조사한 $\mathrm{CON}+\mathrm{UVB}$ 처리구간에서 $180.47 \%$ 의 MMP-1 활성을 나타내었으나, GPA-III 구간 $0.05-0.5 \mu \mathrm{g} / \mathrm{mL}$ 농도 처리를 통해 $69.67-100.87 \%$ 의 가장 높은 MMP-1 활성 저해를 나타내었다. 또한, GPA-I 및
GPA- ㅍ 구간에서도 78.28-156.56\% 및 76.96-111.33\%의 활 성을 나타내어 농도 유의적인 MMP-1 저해 활성을 나타내 었다. 이러한 결과는, 황산다당에 의해 MMPs(metalloproteinases)와 특이적 저해제인 TIMPs(Tissue inhibitor of metalloproteinase)와의 결합을 증진하여 elastase 활성을 저 해한다고 보고되어 있으며(31), Cha 등(32)은 후코이단 분 자량이 화장품 기능성에 미치는 연구에서 분자량 31-160 $\mathrm{kDa}$ 구간 모두에서 우수한 활성을 나타내었으며, 특히, 100 $\mathrm{kDa}$ 분자량에서 다른 분자량보다 높은 저해 활성을 나타낸 다고 보고하여 본 연구결과와 유사한 경향을 나타내었다. 따라서, 불등풀가사리 유래 산가수분해된 다당류는 피부 구조 단백질의 분해를 억제하여 피부 주름 생성 억제에 도움을 줄 수 있을 것으로 판단된다.
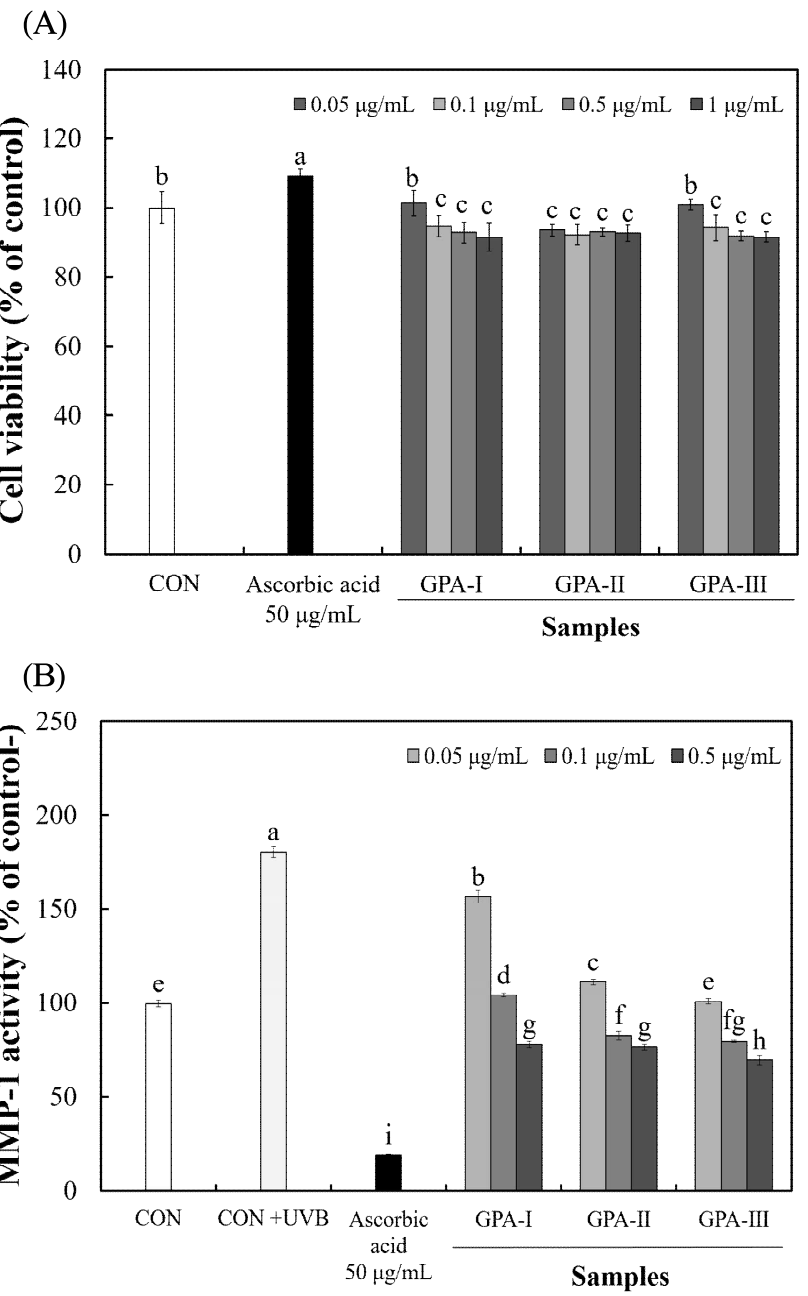

Fig. 3. Effect of polysaccharides with different molecular weights from Gloiopeltis furcata on MMP-1 activity of HS68 cell.

(A), Cytotoxicity; (B), MMP-1 activity.

The expression of MMP-1 in the UVB irradiated human dermal fibroblasts. GPA- I, polysaccharides with molecular weight $<10 \mathrm{kDa}$; GPA- I, polysaccharides with molecular weight 10-100 $\mathrm{kDa}$; GPA-III, polysaccharides with molecular weight $>100 \mathrm{kDa}$. 


\section{Pro-collagen 생합성}

콜라겐은 피부의 섬유아세포에서 생성되는 주요 기질 단백질로 피부 세포 지탱, 세포 분활과 분화 유도 등의 기능 을 가지고 있다. 이러한 콜라겐은 중합 반응이 일어날 때 콜라겐 분자로부터 절단 및 분리되는 기능을 가진 것으로 알려져 있으며(33), 프로펩티드 함량 측정을 통해 세포내의 콜라겐 생합성 정도를 Fig. 4에 나타내었다. HS68 세포주에 $\mathrm{UVB}$ 를 조사한 결과 $\mathrm{CON}$ (UVB 무처리)에 비해 $\mathrm{CON}+$ (UVB 처리)에서 콜라겐 생합성을 $44.42 \%$ 저해 하였다. UVB 조사 후 분자량별 다당류를 처리하였을 때 pro-collagen 생합성능은 GPA-III 0.05-0.5 $\mathrm{\mu g} / \mathrm{mL}$ 농도에서 64.92-77.80\%로 가장 높은 생합성 증진을 나타내었으며, GPA- I 및 GPA- ㅍ 구간 0.05-0.5 $\mathrm{\mu g} / \mathrm{mL}$ 농도에서도 각각 58.84-69.326\% 및 58.64-70.17\%로 pro-collagen 생합성을 농도 의존적으로 증진하는 것으로 나타났다. 이는, Shin 등(34)의 히알루론산나트륨의 분자량 크기에 따른 collagen 합성 및 피부 흡습 연구에서 분자량 크기 $(1-1500 \mathrm{kDa})$ 가 증가함에 따라 콜라겐 합성률은 증가하였으며 $100 \mathrm{kDa}$ 이 하에서 인공 피부 투과율이 현저히 증가하여 피부 장벽을 통과하여 기저층을 지나 안쪽까지 흡수할 수 있다고 보고하 였다. 따라서, 불등풀가사리 유래 산가수분해된 다당류는 피부 주름 형성과 밀접한 관련이 있는 콜라겐 합성 촉진을 통해 피부 주름 개선 소재로 활용 가능할 것으로 사료된다.

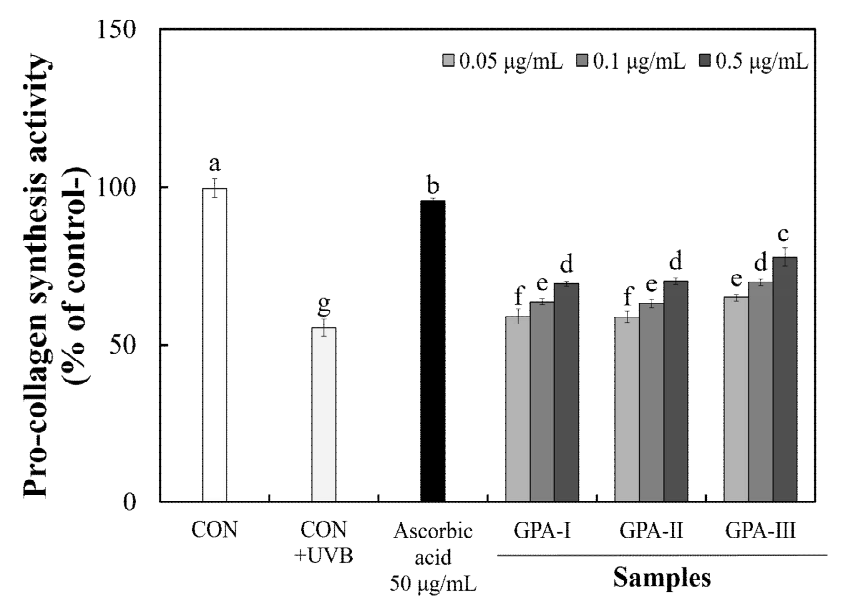

Fig. 4. Pro-collagen synthesis of polysaccharides with different molecular weights from Gloiopeltis furcata in HS68 cell.

GPA- I, polysaccharides with molecular weight $<10 \mathrm{kDa}$; GPA- II, polysaccharides with molecular weight 10-100 kDa; GPA-III, polysaccharides with molecular weight $>100 \mathrm{kDa}$.

\section{요 약}

본 연구는 불등풀가사리로부터 분리된 조다당류와 산가 수분해된 다당류의 분자량에 따른 이화학적 품질특성과 항산화 활성 및 피부 주름 개선 효과를 확인하였다. 산가수
분해 분자량별 다당류의 수율은 $100 \mathrm{kDa}$ 이상에서 $29.6 \%$ 로 가장 높았으며, $10 \mathrm{kDa}$ 이하에서 $10.4 \%$ 로 가장 낮았다. 이화학적 특성으로 총당, uronic acid, sulfate 함량은 100 $\mathrm{kDa}$ 이상에서 각각 $85.82 \%, 32.85 \mathrm{~g} / 100 \mathrm{~g}$ 및 $39.04 \%$ 로 조다 당에 비해 증가하였다. 색도은 분자량이 증가함에 따라 $\mathrm{L}$ 값, $\mathrm{a}$ 값 및 $\mathrm{b}$ 값이 감소하였으며, 점도는 분자량이 높을수록 증가하였다. ORAC 활성은 $100 \mathrm{kDa}$ 이상에서 $180.07 \mu \mathrm{M}$ 을 나타내어 조다당 $34.70 \mu \mathrm{M}$ 에 비해 항산화활성이 우수하였 다. L132 세포 사멸에 대한 보호효과는 $\mathrm{H}_{2} \mathrm{O}_{2}$ 처리 구간 대비 분자량 $100 \mathrm{kDa}$ 이상 $(0.5-5 \mu \mathrm{gg} / \mathrm{mL})$ 에서 $87.34-103.85 \%$ 로 세포 활성이 증가하여 세포 보호효과를 나타내었다. MMP-1 활성은 세포에 UVB를 조사한 후 분자량 $100 \mathrm{kDa}$ 이상 $0.05-0.5 \mu \mathrm{g} / \mathrm{mL}$ 농도에서 $69.67-100.87 \%$ 의 저해 활성 을 나타내었다. 또한, pro-collagen 생합성 역시 UVB를 조사 한 후 분자량 $100 \mathrm{kDa}$ 이상 $0.05-0.5 \mu \mathrm{g} / \mathrm{mL}$ 농도에서 64.91-77.80\%의 합성능을 나타내어 농도 의존적으로 증가 하는 것을 확인하였다. 따라서, 불등풀가사리 유래 산가수 분해된 다당류의 분자량에 따른 주름 개선 효과를 통해 피부 항노화 기능성 소재로 다양하게 활용 가능할 것으로 사료된다.

\section{References}

1. Yoo JM, Kang YJ, Pyo HB, Choung ES, Park SY, Choi JH, Han GJ, Lee CH, Kim TJ (2010) Anti-wrinkle effects of Korean rice wine cake on human fibroblast. J Life Sci, 20, 1838-1843

2. Park K, Lee JH (2008) Protective effects of resveratrol on UVB-irradiated HaCaT cells through attenuation of the caspase pathway. Oncol Rep, 19, 413-417

3. Fisher GJ, Datta SC, Talwar HS, Wang ZQ, Varani J, Kang S, Voorhees JJ (1996) Molecular basis of sun-induced premature skin ageing and retinoid antagonism. Nature, 379, 335-339

4. Fisher GJ, Kang S, Varani J, Bata-Csorgo Z, Wan Y, Datta S, Voorhees JJ (2002) Mechanisms of photoaging and chronological skin aging. Arch Dermatol, 138, 1462-1470

5. Kwon EJ, Park HJ, Kim MM, Lee KR, Hong I, Lee DG, Oh YH (2014) Effent of Ulmus macrocapa ethanolic extracts on anti-oxidant activity and melanin synthesis in B16F1 cells. J Life Sci, 24, 946-951

6. Jang MJ, Jun DH, Kim SH, Han SI, Lee JT (2013) Anti-wrinkle effect of chestnut leaf. J Life Sci, 23, 751-756

7. Zurick KM, Qin C, Bernards MT (2012) Adhesion of 
MC3T3 E1 cells bound to dentin phosphoprotein specifically bound to collagen type I. J Biomed Mater Res A, 100, 2492-2498

8. Park SY, Jung BM, Choi YH, Bae SJ (2005) Growth inhibition effects of cancer cell lines by Gloiopeltis furcata fractions in vitro. J Korean Soc Food Sci Nutr, 34, 771-775

9. Do JR, Nam YJ, Park JH, Jo JH (1997) Studies on chemical composition of red algae. J Korean Fish Soc, 30, 428-431

10. Wang X, Wang J, Zhang J, Zhao B, Yao J, Wang Y (2010) Structure - antioxidant relationships of sulfated galactomannan from guar gum. Int J Biol Macromol, 46, 59-66

11. Chang DS, Cho HR, Lee HS, Park MY, Lim SM (1998) Development of alginic acid hydrolysate as a natural food preservative for fish meat paste products. Korean J Food Sci Technol, 30, 823-826

12. Pugh N, Ross SA, ElSohly MA, Pasco DS (2001) Characterization of Aloeride, a new high-molecularweight polysaccharide from Aloe vera with potent immunostimulatory activity. J Agric Food Chem, 49, 1030-1034

13. Saha AK, Brewer CF (1994) Determination of the concentrations of oligosaccharides, complex type carbohydrates, and glycoproteins using the phenolsulfuric acid method. Carbohydr Res, 254, 157-167

14. Lowry OH, Rosebrough NJ, Farr AL, Randall RJ (1951) Protein measurement with the folin phenol reagent. J Biol Chem, 193, 265-275

15. Cesaretti M, Luppi E, Maccari F, Volpi N (2003) A 96-well assay for uronic acid carbazole reaction. Carbohydr Polym, 54, 59-61

16. Dodgson KS, Price RG (1962) A note on the determination of the ester sulphate content of sulphated polysaccharides. Biochem J, 84, 106-110

17. Talcott ST, Lee JH (2002) Ellagic acid and flavonoid antioxidant content of muscadine wine and juice. J Agric Food Chem, 50, 3186-3192

18. Chiang HM, Lin TJ, Chiu CY, Chang CW, Hsu KC, Fan PC, Wen KC (2011) Coffea arabica extract and its constituents prevent photoaging by suppressing MMPs expression and MAP kinase pathway. Food Chem Toxicol, 49, 309-318

19. Kim YM, Do JR, In JP, Park JH (2005) Angiotensin I converting enzyme (ACE) inhibitory activities of laver (Porphyra tenera) protein hydrolysates. Korean J Food
Nutr, 18, 11-18

20. Hou Y, Wang J, Jin W, Zhang H, Zhang Q (2012) Degradation of Laminaria japonica fucoidan by hydrogen peroxide and antioxidant activities of the degradation products of different molecular weights. Carbohydr Polym, 87, 153-159

21. Chen H, Zhang M, Xie B (2004) Quantification of uronic acids in tea polysaccharide conjugates and their antioxidant properties. J Agric Food Chem, 52, 3333-3336

22. Lim JK (2014) A review of the usability of fucoidan extracted from brown seaweed as a functional ingredient of cosmetics. Kor J Aesthet Cosmetol, 12, 447-452

23. Fukumoto LR, Delaquis P, Girard B (1998) Microfiltration and ultrafiltration ceramic membranes for apple juice clarification. J Food Sci, 63, 845-850

24. Lee DS, Kim HR, Pyeun JH (1998) Effect of low-molecularization on rheological properties of alginate. Korean J Fish Soc, 31, 82-89

25. Alarcon E, Campos AM, Edwards AM, Lissi E, Lopez-Alarcon C (2008) Antioxidant capacity of herbal infusions and tea extracts: A comparison of ORACfluorescein and ORAC-pyrogallol red methodologies. Food Chem, 107, 1114-1119

26. Lee DH, Hong JH (2014) Physicochemical properties and antioxidant activities of polysaccharides from Styela plicata by extraction conditions. J Chitin chitosan, 19, 130-137

27. Zhou C, Wang Y, Ma H, He R (2008) Effect of ultrasonic degradation on in vitro antioxidant activity of polysaccharides from Porphyra yezoensis (Rhodophyta). Food Sci Tech Int, 14, 479-486

28. Kim MJ, Choi JH, Kwon SH, Kim HD, Bang MH, Yang SA (2013) Characteristics of fermented dropwort extract and vinegar using fermented dropwort extract and its protective effects on oxidative damage in rat glioma C6 cells. Korean J Food Sci Technol, 45, 350-355

29. Lee MH (2013) Structural elucidation and bioactivities of UV-absorbing materials isolated from brown algae Ishige sinicola and red algae Gloiopeltis furcata. $\mathrm{Ph} \mathrm{D}$ Thesis, National Mokpo Maritime University, Korea, p 77

30. Suganuma K, Nakajima H, Ohtsuki M, Imokawa G (2010) Astaxanthin attenuates the UVA-induced up-regulation of matrix-metalloproteinase-1 and skin fibroblast elastase in human dermal fibroblasts. J Dermatol Sci, 58, 136-142

31. Senni K, Gueniche F, Foucault-Bertaud A, IgondjoTchen S, Fioretti F, Colliec-Jouault S, Durand P, Guezennec J, Godeau G, Letourneur D (2006) Fucoidan 
a sulfated polysaccharide from brown algae is a potent modulator of connective tissue proteolysis. Arch Biochem Biophys, 445, 56-64

32. Cha SH, Ahn MW, Lee JS, Kim YS, Kim DU, Byun TG, Park KP (2012) The effect of fcoidan molecula weight on cosmetic function. Korean Chem Eng Res, 50, 604-609
33. Kim SH, Jung H, Shin YC, Ko SG (2008) Research of traditional herbal medicines for anti-aging, inhibition effect of wrinkle and whitening effect in the skin. J Physiol Pathol Korean Med, 22, 691-698

34. Shin EJ, Park JW, Choi JW, Seo JY, Park YI (2016) Effects of molecular weights of sodium hyaluronate on the collagen synthesis, anti-inflammation and transdermal absorption, J Soc Cosmet Sci Korea, 42, 235-245 